\title{
Oral Presentation Skills in Business and Strategic Communication: An Analysis of the Impact of Communication Apprehension
}

\author{
Ephraim Okoro, PhD \\ School of Business \\ Howard University \\ 2400 Sixth St NW \\ Washington, DC 20059, USA
}

\begin{abstract}
Communication competence represents one of the critical skills for achieving a competitive advantage in the $21^{\text {st }}$ century workplaces. Oral presentations and written communication are essential exercises and assignments in business education for developing real-world strategic and managerial skills. These interdependent communication skills and competence present unique challenges for business communication students as they prepare to join the workforce. This paper examines students' writing effectiveness as well as explores their attitudes towards oral presentations in business and professional communication course. Using Personal Report of Communication Apprehension-24 (PRCA) and Situational Communication Apprehension Measure (SCAM), a survey was collected from approximately 400 students via pre-test and post-test in the spring and fall of 2017. Survey findings identified fundamental communication variables affecting oral presentations to groups as well as self-perceived competency in public presentation contexts. The study then concludes that consistency of rigorous oral presentation and writing assignments during class sessions would improve students' level of effectiveness and proficiency.
\end{abstract}

Keywords: Communication apprehension, Stage-fright, Nervousness, Low self-esteem, Oral presentation

\section{Introduction}

Over the past two years, there has a need to improve students' writing skills and oral presentation competence in business communication at the undergraduate level in the School of Business at Howard University. This need arose from concerns expressed at faculty meetings in which the quality of students' writing and their standard of expressiveness were critically analyzed. Essentially, this requirement resulting from faculty expectation is consistent with Howard University's School of Business core competency of "written and oral communication skills," derived from the American Association of Collegiate Schools of Business (AACSB) learning standards. Consistently, Bovie and Thill (2014) reiterated that AACSB in conducting periodic curriculum reviews of business schools reaccreditation identified core competencies designed to promote and foster continuous quality improvement in business management education. Additionally, as a significant component of quality assurance, there is a constant emphasis on curriculum quality and consistency of rigorous teaching standards in order to maintain AACSB accreditation. Business schools across the United States desiring to maintain high academic standards are required to ensure learning experiences in critical areas, including communication skills, analytic skills, and reflective thinking, specifically to prepare business students for competitive advantage in the global workforce.

As the Business School at Howard University prepares for AACSB team visit, creative course redesign was embarked upon to meet the challenging reaccreditation standards. Therefore, business communication faculty members were charged with the responsibility to redesign, revamp, or restructure business communication course to improve students' communication skills in two distinct phases - writing effectiveness and oral presentation competence. Furthermore, the course is expected to introduce strategies and methods for enhancing students' current attitudes towards oral presentation assignments, increase the consistency of in-class written assignments, modify and expand grading standards, and increase the level of rigor in business communication assignments. Emphasizing the need for creative course design, Alford \& Sweat (2018, P. 1) explained in the current edition of the Teaching Professor that "creativity in education doesn't mean coming up with a revolutionary new idea, 
complete reinvention of something, or a holistic development of a new program; creativity means doing something original or unique" that meets a specific standard to accomplish a set of objectives. The authors stressed that educational activities or programs, from time to time, requires repackaging, reemphasizing, or improving the process or sequence that some experts had already developed and used effectively over the years for quality assurance.

Presently, the business communication course in the School of Business indicates a significant improvement in students' ability to create effective sentences, develop coherent paragraphs, and adapt messages to appropriate audiences. As suggested by business communication scholars and consultants, (Bovee \& Thill, 2015; Cardon, 2014; \& Shown \& Snyder, 2015), planning, framing, and writing professional messages should conform to the specific categories and allotments of $50 \%$ for planning, $25 \%$ for writing, and $25 \%$ for content editing/proofreading. Accordingly to Alford \& Sweat (2018, p.1), adding one's own style, format, and standard to an existing educational approach bothers on creativity or improvement that contributes to academic enterprise and experience. The authors added that "sometimes all that is required to take a course or lesson from sleepy to exciting is a small, but personal, creative adaptation." In the modern era of information technology, it is much easier to modify an existing program than to develop an entirely new one. Many programs, courses, and activities in higher education could be redesigned effectively and efficiently, adding a lot of learning experience in the system for students. Indeed, with excitement embedded in a program of study, students' participation or engagement would be encouraged, regardless of the level of rigor and challenge.

Significance of the Study:

An assessment of students written assignments in business and professional communication over the past three academic years clearly indicates competence in content objectivity, familiarity with message formatting and style, designing messages for readability, and appropriate use of tone to buttress writers' integrity. These criteria were based on Bovee and Thill (2015) and Shown \& Snyder (2018) guidelines for framing professional and strategic business messages. In the process of course design in a learning environment, Alford \& Sweat (2018) suggested collaboration among faculty members and team work in order to achieve a more coherent and comprehensive content standard, It was noted that a lack of creativity in the education enterprise was as a result of much independent working and thinking by academic administrators, faculty, and scholars. Evidently, working in isolation stifles growth in program redesign and content modification. Authors Alford \& Sweat encouraged team work because collaboration with colleagues fosters expansion, creativity, and scholarly replication.

The institutional climate for teaching and adopting change was explained in The Teaching Professor of April edition, 2018. Alford and Sweat (2018 p.7) noted the correlation between the climate for teaching at academic institutions and its impact on the learning environment. It was stressed that a university's culture should generally support and encourage teaching and learning with appropriate policies, framework, and attitude to motivate change initiation, implementation, and acceptance. Similarly, the academic environment should engender student-centered improvement and faculty-collaborated teaching style. Higley (2018) recommended the significance of encouraging classroom participation through in-class reviews, group discussions, and faculty guided presentations. The author further explained that in-class reviews work effectively because questions are clearly discussed, and the class timeframe allows students to prepare answers, engendering adequate confidence in students' ability to provide specific and correct answers with thoughtful elaborations.

Over the past two academic years, a few students were charged with either intentional or unintentional plagiarism in their final projects, written class assignments, or term papers. This writing deficiency which plagued the student body was effectively addressed as increased emphasis was placed on clarity of written materials, effective use of sources to substantiate ideas and concepts, especially in preparing complex assignments such as final projects, term papers, and case analyses. The overall content of students' work was evaluated through submission of multiple drafts for cross-checking sources used, and the correctness of citation methods for paraphrasing and quoting information. Additionally, students are required to elaborate on citations to demonstrate a sound understanding of their subject matter.

The challenging phase of a business communication course redesign and restructure is the inclusion of oral presentation and class participation, which required students' independent or collective presentation of written assignments. In addition, students' participation in class discussions as well as in group/team projects is required in the oral presentation phase of course redesign and restructure. 


\section{The Need for Course Expansion (problem statements)}

A majority of undergraduate students preparing to join the workforce after graduation indicate a troubling deficiency in communication competence, especially in critical skills of writing and oral presentation. The replacement of multiple choice questions with written assignment and presentation exercises in the course syllabus reveal a serious need to improve writing assignments as well as oral presentations. Students are not able to articulate coherently in their written essays and answers. As part of the ongoing effort to redesign and revamp business communication course in business communication, assignments requiring oral presentations, class participation, assignments requiring group-work were introduced to expose students to a more rigorous writing assignments. These types of assignment were required on a weekly basis, making it possible for students to practice and improve their writing proficiency. As an incentive or motivation to generate students' interest in oral presentation, points were given for assignments involving class participation, discussions, and presentations. Some students frowned, complained, and demonstrated dissatisfaction with oral presentation being part of grading requirement for deter. Some of the students stayed away from classes on the days that oral presentation assignments were scheduled, and the "extremists" among them were consistently absent from class sessions; and when they attended classes, they were unwilling to engage in discussions. They described oral presentation assignments as inappropriate, time-wasting, and incompatible with their personality.

\section{Review of the Literature}

Business education, especially professional or strategic communication, continues to focus on preparing students to acquire critical skills and competencies needed for leadership careers in the workplaces of the $21^{\text {st }}$ century. Past and present studies indicate that students' inability to participate in oral presentations was traced to a number of variables, such as low self-esteem, stage-fright, or communication apprehension. Independent of each other, Rocca (2010) and Stewart (2013) explained that the phenomenon of communication apprehension originated from students' real or imaginary fear, anxiety, or discomfort with interactions with groups or (a formal or informal audience). These studies concluded that individuals' low-esteem, shyness, avoidance, and introversion were factors associated with communication apprehension. Therefore, students' inability or unwillingness to present or participate in oral presentations in class sessions or in other public contexts could be controlled in order to minimize its impact in adult age, in a professional setting. Emphasizing oral presentations as essential components of students' skills acquisition, Karim \& Shah (2012) suggested the use of class presentation assignments designed to improve students' ability to demonstrate interpersonal effectiveness, self-confidence, and working in teams.

Stewart \& Tassie (2013) and Rocca (2010) noted that organizations are placing increased emphasis on job applicants' ability to express themselves professionally in writing and verbally as a measure of communication competence, which is a required skill for administrative leadership. In order to prepare business communication students for competitive managerial positions, there is certainly a need to improve their oral presentations whether for special occasions or extemporaneously. Therefore, a significant portion of business communication class assignments should be designed to include individual discussions, group or independent presentations as well as report-writing.

Researchers (Neer, 1987; Robinson, 1997; and Rocca, 2010) identified presentations contexts and operationalized them as classrooms, group discussions and panels, team meetings, one-on-one conversations, and class interactions. Furthermore, communication scholars (Young, 1991; Weaver \& Jiang, 2005) cautioned that a lack of comfort and confidence in self-expression, engaging effectively with people, or making a formal presentation to formal or informal group could largely inhibit students' professional success. Furthermore, in recent years employers have listed interpersonal competence, cross-cultural communication, interacting in teams, and effective organizational communication skills at the top of desired skill set for selecting job applicants for senior level positions. Other studies on the significance of oral presentations in the workplace (Holbrook, 1987; Fassinger, 1995; Frymier, 1993) concluded that communication apprehension could potentially prevent highly capable students from reaching their desired goals as a result of demonstrated failure to articulate in public. Similarly, more than four decades ago McCroskey (1970) determined that undetected communication apprehension was the product of low self-esteem, self-doubt, timidity, and unnecessary aggression among students, and leading to confrontation in informal settings. Evidently, communication apprehension has been instrumental for employees who had served their organizations for a long time not been considered for a leadership position when he opportunity became available. 
In their analysis of the impact of communication apprehension on student retention and success, McCroskey \& Payne (1986) pointed out the need to monitor students' communication anxiety through consistent presentation assignments in order to encourage development of healthy oral presentation skills. In a recent study, Czekanski \& Wolf (2013) concluded that most communication apprehensive students possess sub-standard communication skills, caused by undetected stages of stage-fright, nervous feelings, and presentation discomfort. Similarly, Frisby, et.al (2014) traced students' unwillingness to take on leadership or managerial opportunities to communication apprehension.

Daly \& Miler (2014) determined that approximately $20 \%$ of 60,000 students' survey over the past ten years suffers from communication apprehension. McCroskey (2015) concurred that some students desire to communicate with classmates, but were impeded by low self-esteem engendered by internal fear or anxiety.

Methodology: A hybrid Approach - Explored Communication Anxiety:

- Modified the PRCA-24 (Personal Report of Communication Apprehension) survey for the classroom environment

- Explored three dimensions

- Impromptu comments and presentations in class

- Participating in group discussions

- Speeches and presentations

$\underline{\text { Participants }}$

- Approximately 400 students participated in the survey

- 140 students took pre-class surveys

- 130 students took post-class surveys

- 128 students took both pre-class and post-class surveys (basis for pre-classes and post-class comparisons)

In an attempt to improve students' oral presentation skills, a survey exploring communication anxiety was distributed based on three dimensions: Impromptu comments and presentations in class, participation in group discussions, and class speeches and oral presentations. Personal Report of Communication Apprehension-24 (McCroskey, 1982) and Situation Communication Apprehension Measure (Richmond, 1978), modified scales for communication apprehension was administered to students in business communication classes in spring and fall semesters 2017. Approximately, 400 students participated in the survey, 140 students took pre-class surveys, and 130 students participated in post-class surveys, and 128 students took both pre-class and post-class surveys in fall and spring semesters.

Faculty member's independent observation of students' presentations was conducted over a period of two semesters to validate students' self-reporting of their oral presentation skills and competences. Specific variables measured were students' impromptu comments during class sessions, participating in group discussions, oral presentations of cases and scenarios, ability to plan presentations, ability to deliver presentations, and ability to present confidently. This survey also attempted to identify oral presentation competence of female and male students in business communication classes. Additional variables for future study would include students' years in college (freshman, sophomore, junior, and senior) to assess whether or not students become self-confident and willing to participate in oral presentations based on the number of years and semesters they have been in college.

\section{Concluding Comments and Recommendation}

Based on Cluster Analysis of Anxiety scores (pre-class and post-class), this preliminary study determined that female students hold considerably more anxiety than their male counterparts in oral presentations and related assignments. Furthermore, it was noted that high-anxiety students are less likely to perceive that they improved their presentations abilities. Finally, students gain significantly more confidence (lower anxiety) after taking a business communication course, especially high anxiety students. Some students tend to overcome the impact of communication apprehension (stage fright, low self-esteem, shyness, introversion, timidity, and presentation discomfort) after taking rigorous written and oral presentation class assignments. A study by Rocca (2010) entitled "Silence is not golden: reducing communication apprehension in the university classroom," it was suggested that students are more motivated, learn better, become better critical thinkers, when answering questions and contributing to class discussions. Further, Howard and Henry (1998) determined that 90\% of course activities that involve class presentation are made by a few students. 
Essentially, one of the fundamental goals of business and strategic communication courses in preparing students for the workforce of the $21^{\text {st }}$ century is encouraging and increasing participation in their classroom assignments by making a conscious effort to transform the classroom learning from an atmosphere of insecurity and anxiety to an environment that fosters and enhances natural communication competence and strengths of students (Neath, 2014).

Indeed, recent and past studies indicate that failure or inability of some students to perform satisfactorily in oral presentations originated from a communication-related anxiety, which could be controlled. The phenomenon of oral presentation anxiety has plagued students, interviewing candidates, and some job-seeking applicants for decades. Data collected from research conducted more than thirty years ago and reviewed for this paper demonstrated that oral communication apprehension or stage-fright is a troubling reality or response from individuals who have a need to make a public presentation in formal or informal occasions. Furthermore, a survey of 2,543 male and female adults conducted by Bruskin Associates (1973) concluded that making oral presentation before a group or an audience was a major fear among Americans and other nationals. McCroskey (1977) explained that data gathered over an eight-year period from nearly 20,000 students at Michigan State University, Illinois State University, and West Virginia University showed that between 15 and 20 percent of students struggled with oral communication apprehension encounters. Therefore, it is paramount that a business communication course or similar courses taught in the business schools should intensify oral presentation activities to cultivate and improve students' performance for various future leadership roles.

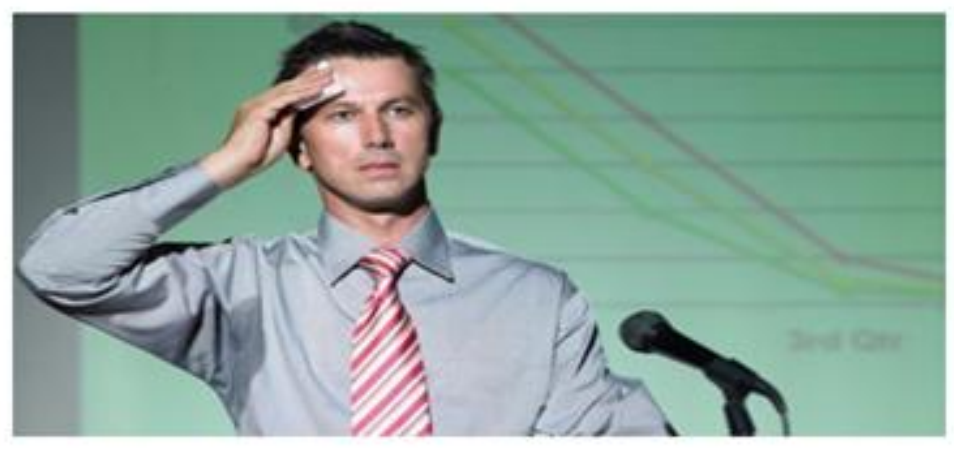

\section{A recent Gallup poll showed that roughly 40 percent of adults/students admit a fear of public speaking (2017)}

\section{Cluster Analysis of Anxiety Scores (Pre-Class) \\ Used K-Means Cluster Analysis}

\section{$18 \%(71 / 400)$ of Students \\ 47\% (188/400) of Students \\ 35\% (141/400) of Students Have High Anxiety Have Moderate Anxiety Have Low Anxiety}

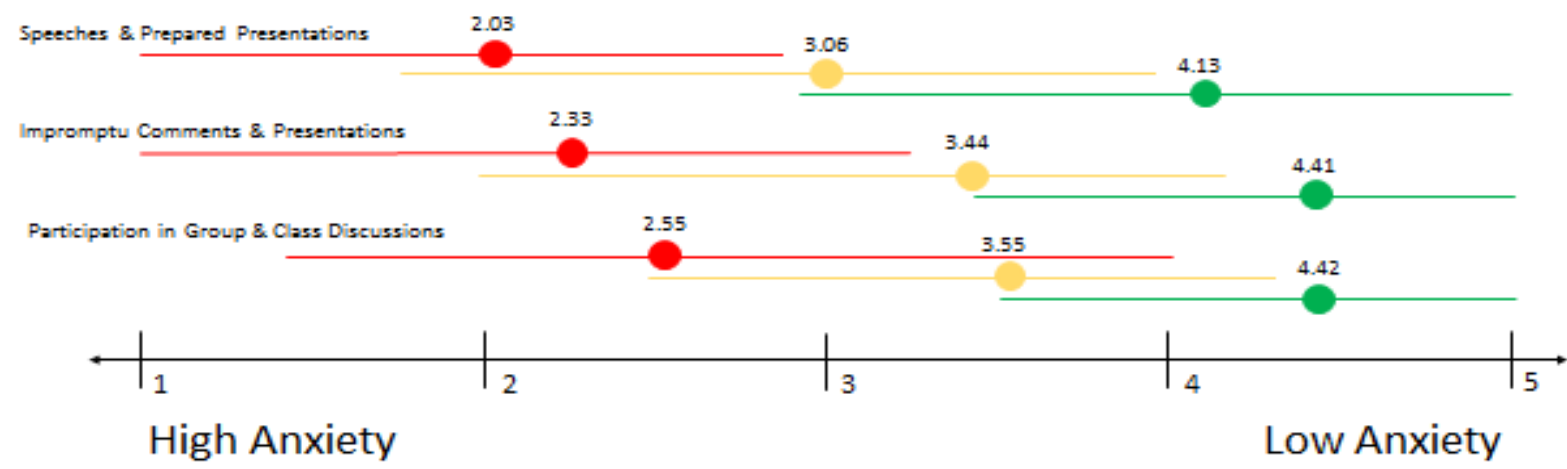


Female Students Hold More Anxiety than Male Students in Class Presentations

\begin{tabular}{c|ccc}
\hline Students & High Anxiety & ModerateAnxiety & Low Anxiety \\
\hline Female & $20.1 \%$ & $48.1 \%$ & $31.8 \%$ \\
Male & $13.2 \%$ & $44.9 \%$ & $41.9 \%$ \\
\hline
\end{tabular}

Students Gain Significantly More Confidence (Lower Anxiety) after a Business Communication Course, especially High-Anxiety Students. . .

\begin{tabular}{|c|c|c|c|c|c|c|c|c|}
\hline & \multicolumn{3}{|c|}{ Pre-Class Anxiety } & \multicolumn{2}{|c|}{ Post-Class Anxiety } & \multirow[b]{2}{*}{$t$} & \multirow[b]{2}{*}{$\begin{array}{c}d \\
\text { Effect Size) }\end{array}$} & \multirow[b]{2}{*}{$p$} \\
\hline & $N$ & M & $S D$ & M & $S D$ & & & \\
\hline \multicolumn{9}{|l|}{ High anxiety } \\
\hline Impromptu Comments in Class & 26 & 2.35 & 0.55 & 2.85 & 0.70 & -3.67 & 0.80 & $.00^{* *}$ \\
\hline Participating in Group Discussions & 26 & 2.61 & 0.43 & 3.04 & 0.62 & -3.65 & 0.81 & $.00^{* *}$ \\
\hline Speeches and Presentations & 26 & 2.04 & 0.46 & 2.62 & 0.67 & -4.97 & 1.02 & $.00^{* *}$ \\
\hline \multicolumn{9}{|l|}{ Moderate anxiety } \\
\hline Impromptu Comments in Class & 67 & 3.42 & 0.32 & 3.68 & 0.56 & -3.76 & 0.60 & $.00^{* *}$ \\
\hline Participating in Group Discussions & 66 & 3.52 & 0.45 & 3.67 & 0.56 & -1.99 & 0.28 & $.05^{*}$ \\
\hline Speeches and Presentations & 66 & 2.99 & 0.44 & 3.33 & 0.55 & -5.07 & 0.68 & $.00^{* *}$ \\
\hline \multicolumn{9}{|l|}{ Low anxiety } \\
\hline Impromptu Comments in Class & 41 & 4.45 & 0.41 & 4.40 & 0.54 & 0.54 & -0.10 & .59 \\
\hline Participating in Group Discussions & 41 & 4.49 & 0.35 & 4.24 & 0.55 & 2.51 & $-0.54(-)$ & $.02^{*}$ \\
\hline Speeches and Presentations & 41 & 4.13 & 0.55 & 4.05 & 0.70 & 0.93 & -0.12 & .36 \\
\hline \multicolumn{9}{|l|}{ All students } \\
\hline Impromptu Comments in Class & 134 & 3.52 & 0.84 & 3.74 & 0.79 & -4.05 & 0.26 & $.00^{* *}$ \\
\hline Participating in Group Discussions & 134 & 3.64 & 0.78 & 3.72 & 0.70 & -1.45 & 0.11 & .15 \\
\hline Speeches and Presentations & 134 & 3.16 & 0.88 & 3.41 & 0.80 & -4.97 & 0.31 & $.00^{* *}$ \\
\hline
\end{tabular}

Note. Based on a 5-point scale: higher scores are associated with less anxiety. A t-test of significance compared pre-class and post-class anxiety. Cohen's $d$ (effect size) suggests that .2 is a small effect size, .5 is a medium effect size, and .8 is a large effect size.

\section{High-Anxiety Students are Less Likely to Perceive They Improved Their Presentation Abilities}

\begin{tabular}{|c|c|c|c|c|c|c|c|c|c|c|c|}
\hline & \multicolumn{3}{|c|}{ Low Anxiety } & \multicolumn{3}{|c|}{ Moderate Anxiety } & \multicolumn{3}{|c|}{ High Anxiety } & \multirow[b]{2}{*}{$F$} & \multirow[b]{2}{*}{$p$} \\
\hline & $N$ & $M$ & $S D$ & $N$ & $M$ & $S D$ & $N$ & $M$ & $S D$ & & \\
\hline \multicolumn{12}{|c|}{$\begin{array}{l}\text { Perceived Improvement in } \\
\text { Presentations }\end{array}$} \\
\hline $\begin{array}{l}\text { Ability to } \\
\text { plan presentations } \\
\text { Ability to deliver }\end{array}$ & 41 & 2.34 & 0.86 & 65 & 2.46 & 0.66 & 26 & 2.04 & 0.72 & 3.05 & $.05^{*}$ \\
\hline $\begin{array}{l}\text { presentations } \\
\text { Ability to present }\end{array}$ & 41 & 2.41 & 0.89 & 65 & 2.42 & 0.66 & 26 & 2.23 & 0.82 & 0.60 & 0.55 \\
\hline confidently & 41 & 2.34 & 0.88 & 64 & 2.47 & 0.71 & 26 & 1.96 & 0.82 & 3.81 & $.03^{*}$ \\
\hline
\end{tabular}

Note. Sca le of 1 = no improvement, 2 = a little improvement, 3 = a lot of improvement. Based on ANOVA test of significance. 


\section{References}

Daly, J.A. \& McCroskey (1975). Occupational choice and desirability As a function of communication apprehension. Journal of Counseling Psychology, 22, 309-313.

Bailey, P., Daley, C.E. Onwuegbuzie, E. J. (1999). Foreign language anxiety and learning style. Foreign Language Annals, 32(1), 63-76'

Bovee, C.L. \& Thill, J.V. (2014). Business Communication Today. Pearson Publishing Group: Boston, MA

Cardon, P.W (2014). Business Communication: Developing leaders for a networked world. New York: NY

Czekanski, K. E. , \& Wolf, Z.R. (2013). Encouraging and evaluating class participation. Journal of University Teaching and Learning. Practice, 10(1), 1-12.

Fassinger, P.A. (1995). Understanding classroom interaction: Students' and professors' contributions to students' silence. The Journal of Higher Education, 66(1), 82-96.

Frisby, B.N. , Berger, E. Burchett, M., Herovic, E. \& Strawser, M.G.

(2014). Participation apprehensive students: The influence of the face support and instructor-student rapport on classroom participation. Communication Education, 63(2), 1-19

Frymier, A.B. (1993). The relationships among communication apprehension immediacy, and motivation to study. Communication Reports, 6(1), 8-17

Holbrook, H.T. (1987). Communication apprehension: The quiet student In your classroom. ERIC Digest

McCroskey, J.C. (1970). Measure of communication-bound anxiety. Speech monographs, 37, 269-277.

McCroskey, J.C. (1977). Oral communication apprehension. Summary of recent theory and research. Human communication research, 4, 78-96.

McCroskey, J.C. (1982). Oral communication apprehension: A reconceptualization. In M. Burgeon (Ed.). Communication Yearbook, 6, (pp 136-170). Beverly Hills. CA: Sage

McCroskey, J.C. \& Payne, S.K. (1986). The impact of communication apprehension on student retention and success: A preliminary report. ACA bulletin, No. 56, 65-69.

Menzel, K.E. ., Crrell, L.J. (1999). . The impact of gender and immediacy on Willingness to talk and perceived learning. Communication Education, 48(1), 31-40.

Weaver, R.R. \& Jiang, Q. (2005). Classroom organization and participation. College students' perceptions. The Journal of Higher Educuation, 76(5), 570-601.

Czekanski, K.E. \& Wolf, Z.R. (2013). Encouraging and evaluating class Participation. Journal of University Teaching and Learning Practice. 10(1), 1-2.

Karim, N.H.A. \& Shah, M.I.A. (2012). Silence is not golden: Investigating Classroom participation anxiety among university students. World Applied Sciences Journal, 20(2), 228-235.

Neer, M.T. (1987). The development of an instrument to measure classroom Apprehension. Communication Education, 36(2), 154-166.

Neath K. (2014). Silence is not golden: Reducing communication Apprehension in the university classroom. Teaching Innovation Projects. Volume 4, Issue National Special Issue.

Neer, M.R., \& Kircher, W. F. (1989). Apprehensives' perception of classroom Factors influencing their class participation. Communication Research Reports, 6(1), 70--77

Robinson III, T.E. (1997). Communication apprehension and the basic public Speaking course: A national survey of in-class treatment techniques. Communication Education, 46(3), 188-197.

Rocca, K.A. (2010). Student participation in the college classroom. An Extended multidisciplinary literature review. Communication Education, 59(2), 185-213

Shwom B. \& Snyder L.G. (2019). Business Communication: Polishing your Professional presence (4th Ed.). Pearson, N.Y: New York

Stewart, F. \& Tassie, K.E. (2011). Changing the atmos'fear' in the public Speaking classroom. International Journal of Humanities, 76(5), 570-601

Weaver, R.R. \& Jiang, Q. (2005). Classroom organization and participation: College students' perceptions. The Journal of Higher Education,76(5), 570-601

Young, D. J. (1991). Creating a low-anxiety classroom environment: What does language anxiety research suggest? The Modern Language Journal, 75(4), 426-439. 